\title{
Evaluation and management of skeletal health in celiac disease: Position statement
}

\author{
Mona A Fouda MD FRCPEdin ${ }^{1}$, Aliya A Khan MD FRCPC ${ }^{2}$, Muhammad Sultan BHSc MD ${ }^{3}$, \\ Lorena P Rios MD², Karen McAssey MD FRCPC ${ }^{4}$, David Armstrong MA MB BChir FRCPC ${ }^{2,5}$
}

\begin{abstract}
MA Fouda, AA Khan, M Sultan, et al. Evaluation and management of skeletal health in celiac disease: Position statement. Can J Gastroenterol 2012;26(11):819-829.
\end{abstract}

OBJECTIVE: To review the evaluation and management of skeletal health in patients with celiac disease (CD), and to make recommendations on screening, diagnosis, treatment and follow-up of low bone mineral density (BMD) in CD patients.

METHODS: A multidisciplinary team developed clinically relevant questions for review. An electronic search of the literature was conducted using the MEDLINE and EMBASE databases from 1996 to 2010. All original studies, reviews and guidelines, both pediatric and adult, were included. A document summarizing the results of the review and proposed recommendations was prepared and underwent multiple revisions until consensus was reached.

RESULTS: At diagnosis, approximately one-third of adult CD patients have osteoporosis, one-third have osteopenia and one-third have normal BMD. Children with CD have low bone mass at diagnosis. Adult and pediatric CD patients are at increased risk of fractures.

DISCUSSION: For adults, serum calcium, albumin, $25(\mathrm{OH})$ vitamin $\mathrm{D}_{3}$, parathyroid hormone and $24 \mathrm{~h}$ urine calcium testing should be performed at diagnosis; patients with 'classic' CD and those at risk for osteoporosis should undergo a dual $\mathrm{x}$-ray absorptiometry scan. An abnormal baseline dual $\mathrm{x}$-ray absorptiometry scan should be repeated one to two years after initiation of a gluten-free diet (GFD). For children, BMD should be assessed one year after diagnosis if GFD adherence is not strict. A GFD is the most important treatment for bone loss. Supplemental antiresorptives may be justified in those who remain at high fracture risk (eg, postmenopausal women, older men) after implementation of a GFD.

CONCLUSION: Current evidence does not support the screening of all CD patients for low BMD at diagnosis. Follow-up BMD assessment should be performed one to two years after initiation of a GFD.

Key Words: Bone; Celiac disease; Osteoporosis reliac disease (CD) is an autoimmune enteropathy that occurs in genetically susceptible individuals (human leukocyte antigen [HLA]-DQ2 and HLA-DQ8) as a result of an immune response to gluten (1).

The clinical presentation of CD is heterogenous, ranging from the classic features of malabsorption, weight loss and steatorrhea, to clinically asymptomatic forms that probably represent two-thirds of CD patients today $(2,3)$.

More than 10 years ago, Ferguson et al (3) likened the CD population to an iceberg, with only the tip visible over the waterline (the classically symptomatic patients), and the main body remaining underwater (the asymptomatic patients). Among the asymptomatic patients, silent cases are defined as those with abnormal mucosal changes on biopsy that return to normal on a gluten-free diet (GFD). Latent CD patients are defined as those with a normal jejunal biopsy but test positive for immunoglobulin (Ig) A endomysial antibody (EMA) and/or IgA-tissue transglutaminase (tTG) (4).

\section{L'évaluation et la prise en charge de la santé squelettique en cas de maladie coliaque : un document de principes}

OBJECTIF : Analyser l'évaluation et la prise en charge de la santé squelettique des patients ayant une maladie cœliaque $(\mathrm{MC})$ et faire des recommandations sur le dépistage, le diagnostic, le traitement et le suivi d'une faible densité minérale osseuse (DMO) chez des patients ayant une MC.

MÉTHODOLOGIE : Une équipe multidisciplinaire a préparé des questions pertinentes sur le plan médical à analyser. Elle a procédé à une recherche électronique des publications de 1996 à 2010, dans les bases de données MEDLINE et EMBASE. Toutes les études originales, les analyses et les lignes directrices, pour les groupes pédiatriques et adultes, en faisaient partie. Un document résumant l'information et proposant des recommandations a été préparé et modifié à de multiples reprises jusqu'à l'atteinte d'un consensus.

RÉSULTATS : Au diagnostic, environ le tiers des patients adultes ayant une $\mathrm{MC}$ présente une ostéoporose, un tiers, de l'ostéopénie et un tiers, une $\mathrm{DMO}$ normale. Les enfants ayant une $\mathrm{MC}$ ont une faible masse osseuse au diagnostic. Les patients des groupes pédiatriques et adultes ayant une MC sont plus vulnérables aux fractures.

EXPOSÉ : Au diagnostic des adultes, il faudrait vérifier le calcium sérique, l'albumine, la $25(\mathrm{OH})$ vitamine $\mathrm{D}_{3}$, la parathyroïde et la calciurie des 24 heures; les patients ayant une $\mathrm{MC}$ " classique " et ceux qui sont vulnérables à l'ostéoporose devraient subir une absorptiométrie biénergétique à rayons X. Lorsque les résultats de départ sont anormaux, il faudrait reprendre cette absorptiométrie de un à deux ans après le début d'un régime sans gluten (RSG). Chez les enfants, la DMO devrait être évaluée un an après le diagnostic si la compliance au RSG n'est pas rigoureuse. Le RSG est le principal traitement de perte de densité osseuse. Des inhibiteurs de la résorption osseuse d'appoint peuvent être justifiés chez les personnes qui présentent un risque élevé de fracture (p. ex., femmes post-ménopausées, homme âgés) après la mise en œuvre du RSG.

CONCLUSION : Les données probantes actuelles n'étayent pas le dépistage de tous les patients ayant une $\mathrm{MC}$ afin de diagnostiquer une faible DMO. Une évaluation de suivi de la DMO devrait être effectuée de un à deux ans après le début du RSG.

The reported prevalence of $\mathrm{CD}$ has increased over the past 10 years recent systematic reviews report a $\mathrm{CD}$ prevalence, measured by screening unselected populations of European ancestry, of nearly 1\% (5), with similar figures reported in North America (6).

Fifty per cent of adults are diagnosed after 50 years of age (7), and population-based studies suggest that $50 \%$ to $90 \%$ of people with CD remain undiagnosed $(8,9)$. Metabolic bone disease in $\mathrm{CD}$ patients has been reported in the literature for more than 70 years (10-12), with greater malabsorption leading to greater bone loss. Even subclinical or silent cases have lower bone mineral density (BMD) than healthy controls $(13,14)$

Many longitudinal studies have confirmed that BMD improves in adult patients who adhere to a GFD $(13,15-19)$.

Given this information, the need for an evidence-based approach to the management of bone disease in patients with $\mathrm{CD}$ was recognized. Our objective is to provide recommendations on which CD patients should be screened for low BMD, the extent of biochemical

${ }^{1}$ College of Medicine, King Saud University, Riyadh, Saudi Arabia; ${ }^{2}$ Department of Medicine; ${ }^{3}$ Michael G DeGroote School of Medicine;

${ }^{4}$ Department of Pediatrics; ${ }^{5}$ Division of Gastroenterology, McMaster University, Hamilton, Ontario

Correspondence: Dr Aliya A Khan, 331-209 Sheddon Avenue, Oakville, Ontario L6J 1X8. Telephone 905-844-5677, fax 905-844-8966,

e-mail draliyakhan@gmail.com

Received for publication January 1, 2012. Accepted January 10, 2012 


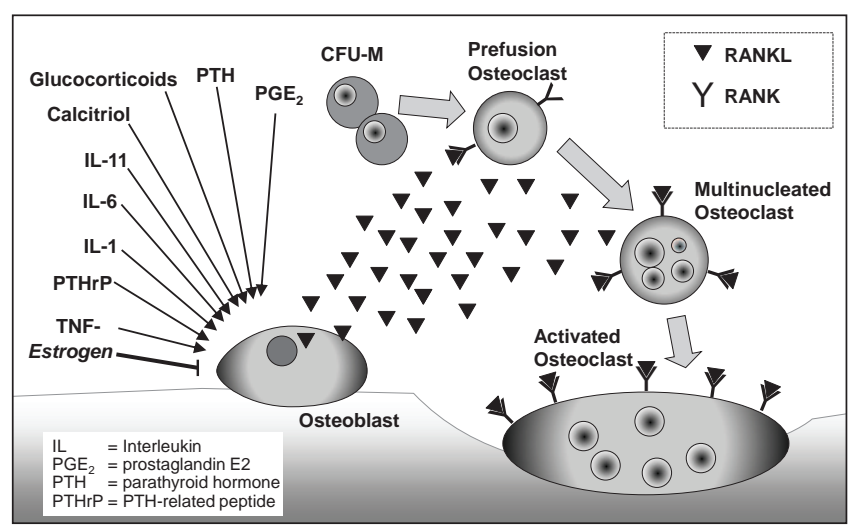

Figure 1) The pathogenesis of bone loss is attributable to increased bone resorption without sufficient corresponding bone formation and mineralization. This may be due to the following: increase in parathyroid hormone (PTH) levels; increase in inflammatory and immunological markers including interleukin (IL) -1, IL-6 and tumour necrosis factor (TNF)-alpha; increase in the receptor activator of nuclear factor kappa (RANK)-B ligand (RANKL)/ osteoprotegrin (OPG) ratio, which causes increased activation and differentiation of osteoclasts; and hypogonadism, particularly in women, with decreases in the levels of circulating estrogen, which also contributes to bone loss. CFU-M Colony-forming unit - Megakaryocyte

assessment that is necessary, appropriate follow-up and management based on BMD and fracture risk.

\section{METHODS}

A multidisciplinary team, including experts in gastroenterology, adult and pediatric endocrinology, metabolic bone disease, rheumatology and nutrition, developed key clinical questions addressing skeletal health in individuals with $C D$. The team reviewed the literature and addressed key clinical questions in optimizing skeletal health and reducing the risk of fracture. The work of the team was supported by the Calcium Disorders Clinic at St Joseph's Healthcare, McMaster University (Hamilton, Ontario).

The key clinical questions addressed were as follows:

1. Which CD patients should be offered BMD tests?

- All CD patients?

- Only CD patients who have a high risk of fragility fractures?

2. What is the role of more extensive biochemical assessment (eg, parathyroid hormone (PTH), 25-hydroxycholecalciferol $\left(25[\mathrm{OH}] \mathrm{D}_{3}\right)$ ?

- Should it be offered to all CD patients?

- Should it be offered only to CD patients with an abnormal dual x-ray absorptiometry scan (DXA)?

- How extensive should the biochemical assessment be in assessing bone mineralization and adequacy of calcium, vitamin $\mathrm{D}$ and phosphate absorption (ie, include $25[\mathrm{OH}] \mathrm{D}_{3}$, PTH concentrations and $24 \mathrm{~h}$ urine calcium)?

3. How should CD patients be followed with respect to skeletal health?

- If initial BMD is normal?

- If initial BMD shows osteopenia or osteoporosis?

- How frequently should the BMD by DXA be repeated?

- How frequently should biochemical tests be repeated?

- What is the relevance of strict adherence to a GFD for skeletal health?

4. What treatments have been proven to prevent fractures in $C D$ patients?

\section{Data sources}

An electronic search of the medical literature relevant to the key clinical questions was conducted using the MEDLINE and EMBASE databases from 1996 to 2010 without language restriction. The search strategy included the following terms: "celiac disease", "osteoporosis", "osteopenia", "low bone mineral density (low BMD)", "vitamin D", "fractures", "parathormone (PTH)", "metabolic bone diseases", "serological markers for celiac disease" and "bone markers". References from relevant articles and clinical guidelines were also reviewed.

\section{Study selection}

All original studies, reviews and clinical guidelines potentially relating to skeletal complications of $\mathrm{CD}$, and with the association between the severity of $\mathrm{CD}$ and biochemical and serological markers in both pediatric and adult populations, were considered for inclusion. If nonEnglish language articles were selected, only the abstracts in English were reviewed; no studies were excluded based on design or methodological quality.

\section{Data extraction}

Fifty studies on BMD and fractures in $\mathrm{CD}$ patients were retrieved and summarized by the first author (MF) in the form of evidence tables, which were circulated to all of the team members. An additional 60 articles were reviewed, and a manuscript was drafted by the first author (MF) based on the information gathered and recommendations were proposed. The recommendations were graded according to the levels of evidence adopted from the Canadian Task Force on Preventive Healthcare (20) (Appendix 1). The draft was revised by each team member until consensus was reached.

\section{What causes bone loss in CD?}

\section{RESULTS}

Pathophysiological aspects: The main mechanisms underlying low BMD in adult CD are secondary hyperparathyroidism and osteomalacia due to calcium and vitamin D malabsorption (21). Markers of bone resorption, such as telopeptides of type I collagen, urinary collagen cross links and urinary hydroxyproline, are increased in the presence of secondary hyperparathyroidism. The resulting effect is net bone loss $(13,17,22,23)$.

Bone health in youth with CD is determined by factors that influence both bone mineral accrual and bone loss. At the conclusion of puberty, growth of the skeleton and bone mass reaches its peak. Studies on bone metabolism in youth with CD indicate that the PTHvitamin D levels are not affected $(24,25)$. Similarly, serum levels of calcium and phosphate, when compared with laboratory reference ranges, are reported to be within normal limits $(24,26)$. There are few pediatric studies that have measured markers of bone formation and bone resorption. Limited data indicate that depressed bone formation rates and enhanced bone resorption may contribute to reduced bone mass in children with CD $(26,27)$.

Immunological and inflammatory changes also contribute to bone mass reduction (Figure 1). Production of proinflammatory cytokines, such as interleukin (IL)-1, IL-6 and tumour necrosis factor-alpha, has been detected in the intestinal mucosa of adult CD patients (28), and increased serum levels of IL-1 and IL- 6 have also been observed $(29,30)$. In untreated adult CD patients, serum IL-6 levels correlate inversely with lumbar BMD (29) and directly with serum PTH and $\mathrm{N}$-telopeptide of type I collagen levels (30). Along with decreased levels of the inhibitory cytokines IL-12 and IL-18, these cytokine imbalances cause bone loss by virtue of direct effects on osteoclastogenesis and osteoblast activity (31-33).

Untreated adult CD patients have been found to have an increased receptor activator of nuclear factor kappa-B ligand/osteoprotegrin ratio, leading to enhanced bone resorption secondary to increased formation, function and survival of osteoclasts (31). Clinical and subclinical hypogonadism in women can also contribute to bone loss $(34,35)$. Similar findings have not been confirmed in men (30).

Bone mineralization and serological markers in CD: PTH levels 
TABLE 1

Bone mineral density (BMD) in untreated celiac disease (CD) in published studies

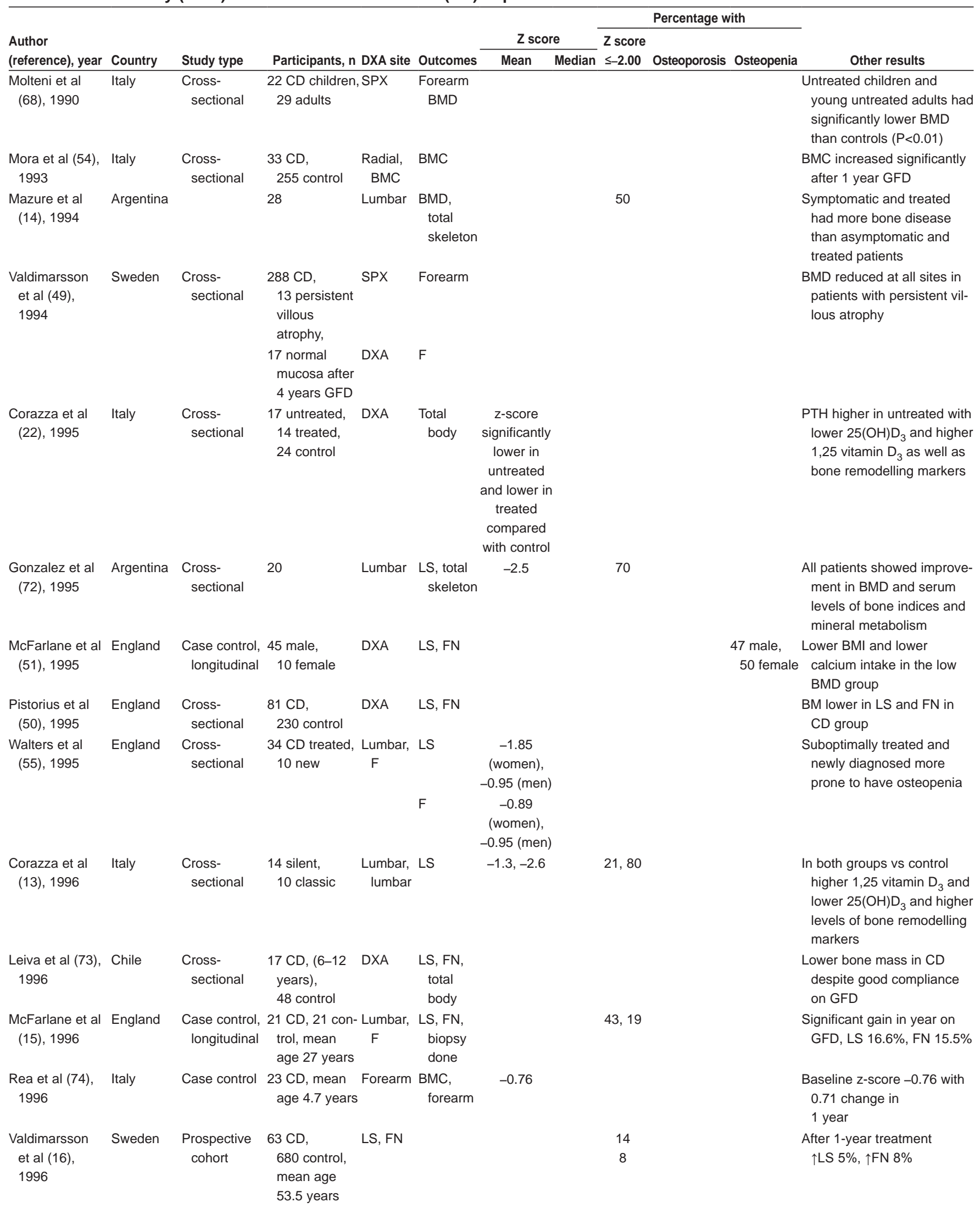


TABLE 1 - CONTINUED

Bone mineral density (BMD) in untreated celiac disease $(C D)$ in published studies

\begin{tabular}{|c|c|c|c|c|c|c|c|c|c|c|c|}
\hline \multirow{3}{*}{$\begin{array}{l}\text { Author } \\
\text { (reference), year }\end{array}$} & \multirow{3}{*}{ Country } & \multirow[b]{3}{*}{ Study type } & \multirow[b]{3}{*}{ Participants, $n$} & \multirow[b]{3}{*}{ DXA site } & \multirow[b]{3}{*}{ Outcomes } & \multirow{2}{*}{\multicolumn{2}{|c|}{ Z score }} & \multicolumn{3}{|c|}{ Percentage with } & \multirow[b]{3}{*}{ Other results } \\
\hline & & & & & & & & \multirow{2}{*}{$\begin{array}{l}\text { Z score } \\
<-2.00\end{array}$} & \multirow{2}{*}{ Osteoporosis } & \multirow[b]{2}{*}{ Osteopenia } & \\
\hline & & & & & & Mean & Median & & & & \\
\hline $\begin{array}{l}\text { Bai et al (75), } \\
1997\end{array}$ & Argentina & Longitudinal & $\begin{array}{l}25 \mathrm{CD}, \\
151 \text { control, } \\
\text { mean age } \\
45 \text { years }\end{array}$ & Lumbar & $\begin{array}{l}\text { LS } \\
\text { total } \\
\text { body }\end{array}$ & $\begin{array}{l}-1.8 \\
-2.2\end{array}$ & & 56 & & $\begin{array}{l}72 \text { LS } \\
84 \text { total } \\
\text { skeleton }\end{array}$ & $\begin{array}{c}84 \% \uparrow \text { BMD LS (mean } \\
\uparrow 12 \% \text { in first year) }\end{array}$ \\
\hline $\begin{array}{l}\text { Ciacci et al } \\
\text { (19), } 1997\end{array}$ & Italy & $\begin{array}{l}\text { Retrospective } \\
\text { cohort }\end{array}$ & $\begin{array}{l}41 \mathrm{CD}, \\
\text { mean age } \\
34.3 \text { years }\end{array}$ & $\begin{array}{l}\text { Lumbar, } \\
\text { F }\end{array}$ & LS, FN & & & & & & $\begin{array}{l}\uparrow 14 \% \text { in LS } \uparrow 10.4 \% \text { in FN } \\
\text { after GFD } 1 \text { year, } \\
\text { pretreatment BMD } \\
\text { predicted respone to GFD }\end{array}$ \\
\hline $\begin{array}{l}\text { Corazza et al } \\
(18), 1997\end{array}$ & Italy & $\begin{array}{l}\text { Prospective } \\
\text { case control }\end{array}$ & $\begin{array}{l}20 \mathrm{CD}, \\
15 \text { control }\end{array}$ & $\begin{array}{l}\text { Lumbar, } \\
\text { F }\end{array}$ & LS, FN & $\begin{array}{l}-2.0 \\
-2.0\end{array}$ & & & & & \\
\hline $\begin{array}{l}\text { Mautalen et al } \\
(17), 1997\end{array}$ & Argentina & & 14 & Lumbar & LS & -1.3 & & 29 & & 79 & \\
\hline $\begin{array}{l}\text { Scotta et al } \\
(46), 1997\end{array}$ & Italy & $\begin{array}{l}\text { Cross- } \\
\text { sectional }\end{array}$ & $\begin{array}{l}66 \text { CD, } \\
76 \text { control }\end{array}$ & Lumbar & & & & & & & $\begin{array}{l}\text { LS DXA was the only param- } \\
\text { eter influenced by age at } \\
\text { diagnosis and duration of } \\
\text { GFD. BMD LS significantly } \\
\text { lower in early diagnosed } \\
\text { patients and/or diet for } \\
<12 \text { months }\end{array}$ \\
\hline $\begin{array}{l}\text { Fornari et al } \\
\text { (29), } 1998\end{array}$ & Argentina & Longitudinal & 16 & Lumbar & LS & & -1.6 & & 44 & 19 & \\
\hline $\begin{array}{l}\text { Mora et al } \\
\qquad(45), 1998\end{array}$ & Italy & $\begin{array}{l}\text { Longitudinal, } \\
\text { cross- } \\
\text { sectional }\end{array}$ & $\begin{array}{l}144 \mathrm{CD} \\
(2.58-20.42) \\
177 \text { control }\end{array}$ & $\begin{array}{l}\text { Whole } \\
\text { skele- } \\
\text { ton }\end{array}$ & $\begin{array}{l}\text { LS total } \\
\text { body }\end{array}$ & & & & & & $\begin{array}{l}\text { Lumbar spine and whole } \\
\text { body BMD significantly } \\
\text { lower at baseline and } \\
\text { improves after } 1 \text { year with } \\
\text { no difference from control }\end{array}$ \\
\hline $\begin{array}{l}\text { Di Stefano et al I } \\
(76), 1999\end{array}$ & Italy & & 16 & $\begin{array}{l}\text { Lumbar, } \\
\text { F }\end{array}$ & $\begin{array}{c}\mathrm{LS}, \\
\mathrm{F}\end{array}$ & $-1.70,-1.93$ & & $\begin{array}{c}44 \\
38\end{array}$ & & & \\
\hline $\begin{array}{c}\text { Kemppainen et } \\
\text { al (56), } 1999\end{array}$ & Finland & Cohort & $\begin{array}{l}\text { 28, mean age } \\
48.6 \text { years } \\
\text { (male); } \\
44 \text { years } \\
\text { (female) }\end{array}$ & $\begin{array}{l}\text { Lumbar, } \\
\text { F }\end{array}$ & LS, F & & & & 33,0 & 49,54 & $\begin{array}{l}\text { BMD } \uparrow \text { or remained stable in } \\
\text { LS } 69 \% \text {, FN } 67 \% \text {. A high } \\
\text { PTH found in } 6 \text { patients, } \\
\text { normalized in } 5 \text { after } 1 \text { year }\end{array}$ \\
\hline $\begin{array}{l}\text { Kemppainen } \\
\text { et al (36), } \\
1999\end{array}$ & Finland & $\begin{array}{l}\text { Cross- } \\
\text { sectional }\end{array}$ & $\begin{array}{l}\text { 77: } 28 \text { newly } \\
\text { diagnosed } \\
49 \text { previously } \\
\text { diagnosed }\end{array}$ & LS, FN & LS FN & & & & 26 & & $\begin{array}{l}35 \% \text { had low BMDs for age } \\
\text { at LS (compared with } 17 \% \\
\text { controls), } 31 \% \text { had } z \text { score } \\
\leq-1 \text { at FN (compared with } \\
16 \% \text { controls) }\end{array}$ \\
\hline $\begin{array}{l}\text { Mora et al } \\
(27), 1999\end{array}$ & Italy & $\begin{array}{l}\text { Longitudinal } \\
\text { cohort }\end{array}$ & $\begin{array}{l}30 \mathrm{CD}, \\
240 \text { control, } \\
\text { mean age } \\
11.4 \text { years }\end{array}$ & $\begin{array}{l}\text { LS, } \\
\text { whole } \\
\text { skele- } \\
\text { ton }\end{array}$ & $\begin{array}{l}\text { Lumbar } \\
\text { and total } \\
\text { body }\end{array}$ & & & & & & $\begin{array}{l}\text { BMD normalized on GFD as } \\
\text { well as bone turnover } \\
\text { marker }\end{array}$ \\
\hline $\begin{array}{l}\text { Mustalahti et al } \\
(17), 1999\end{array}$ & Finland & $\begin{array}{l}\text { Cross- } \\
\text { sectional }\end{array}$ & $\begin{array}{l}19 \text { CD asymp- } \\
\text { tomatic, mean } \\
\text { age } 45 \text { years, } \\
30 \mathrm{CD} \text { symp- } \\
\text { tomatic, mean } \\
\text { age } 44 \text { years }\end{array}$ & $\begin{array}{l}\text { Lumbar, } \\
\mathrm{FN}\end{array}$ & LS FN & & & & & & $\begin{array}{l}\text { Significantly increased LS } \\
\text { (8/19) and FN (10/19) in } \\
\text { silent mean T-score LS } \\
-1.9 \text { silent LS -0.9 FN; } \\
-1.1 \text { symptomatic }-0.8\end{array}$ \\
\hline $\begin{array}{l}\text { Valdimarsson } \\
\text { et al (77), } 1999\end{array}$ & Sweden & & 29 & Lumbar & LS & & -1.120 & & & & \\
\hline $\begin{array}{l}\text { Bardella et (78), } \\
2000\end{array}$ & & Case control & $\begin{array}{l}71 \text { CD } \\
142 \text { control, } \\
\text { mean age } \\
27 \text { years }\end{array}$ & Lumbar & LS & & & & & & $\begin{array}{l}\text { LS BMD significantly lower } \\
\text { than control }\left(0.9 \mathrm{~g} / \mathrm{cm}^{2} \mathrm{vs}\right. \\
\left.1.1 \mathrm{~g} / \mathrm{cm}^{2}\right)\end{array}$ \\
\hline $\begin{array}{l}\text { Di Stefano et al } \\
(52), 2000\end{array}$ & Italy & & $\begin{array}{l}21 \text { silent } \\
18 \text { classic }\end{array}$ & $\begin{array}{c}\text { Lumbar } \\
\text { F }\end{array}$ & $\begin{array}{r}\text { LS } \\
F\end{array}$ & $\begin{array}{l}-1.1 \text { silent, } \\
-2.5 \text { classic, } \\
-1.2 \text { silent, } \\
-2.5 \text { classic }\end{array}$ & & & & & \\
\hline
\end{tabular}


TABLE 1 - CONTINUED

Bone mineral density (BMD) in untreated celiac disease (CD) in published studies

\begin{tabular}{|c|c|c|c|c|c|c|c|c|c|c|c|}
\hline \multirow[b]{2}{*}{$\begin{array}{l}\text { Author } \\
\text { (reference), year }\end{array}$} & \multirow[b]{2}{*}{ Country } & \multirow[b]{2}{*}{ Study type } & \multirow[b]{2}{*}{ Participants, $\mathrm{n}$} & \multirow[b]{2}{*}{ DXA site } & \multirow[b]{2}{*}{ Outcomes } & \multicolumn{2}{|c|}{ Z score } & \multicolumn{3}{|c|}{ Percentage with } & \multirow[b]{2}{*}{ Other results } \\
\hline & & & & & & Mean & $\overline{M e d i a n}$ & $\begin{array}{l}Z \text { score } \\
\leq-2.00\end{array}$ & Osteoporosis & Osteopenia & \\
\hline $\begin{array}{l}\text { Sategna- } \\
\text { Guidetti et al } \\
(57), 2000\end{array}$ & Italy & Longitudinal & $\begin{array}{l}8611 \text { asymp- } \\
\text { tomatic, mean } \\
\text { age } 29 \text { years }\end{array}$ & $\begin{array}{l}\text { Lumbar, } \\
\qquad \mathrm{F}\end{array}$ & $\begin{array}{l}\text { LS, FN; } \\
\text { biopsy } \\
\text { done }\end{array}$ & $-1.5,-1.8$ & & & 26 & 40 & $\begin{array}{l}83.7 \% \uparrow \text { by } 1 \text { year, } \uparrow 5.3 \% \\
\text { LS }\end{array}$ \\
\hline $\begin{array}{l}\text { Valdimarsson } \\
\text { et al (37), } \\
2000\end{array}$ & Sweden & $\begin{array}{l}\text { Prospective } \\
\text { cohort }\end{array}$ & $\begin{array}{l}105 \mathrm{CD} \\
942 \text { Control }\end{array}$ & $\begin{array}{l}\text { Lumbar, } \\
\text { F }\end{array}$ & $\begin{array}{l}\text { LS } \\
\text { T Hip; } \\
\text { biopsy } \\
\text { done }\end{array}$ & & $\begin{array}{l}-0.72 \\
-0.79\end{array}$ & & & & $\begin{array}{l}27 \% \uparrow \text { PTH with lower BMD } \\
\text { and lower } 25(\mathrm{OH})_{\mathrm{D} 3} \text {. Also } \\
\text { more than one-half of } \\
\text { those remained with low } \\
\text { BMD and atrophic mucosa }\end{array}$ \\
\hline $\begin{array}{l}\text { Vazquez et al } \\
(62), 2000\end{array}$ & Argentina & & 51 & Lumbar & LS & & -1.3 & & & & \\
\hline $\begin{array}{l}\text { Kalayci et al } \\
\text { (79), } 2001\end{array}$ & Turkey & $\begin{array}{l}\text { Prospective } \\
\text { cohort }\end{array}$ & $\begin{array}{l}32 \text { CD children, } \\
82 \text { control }\end{array}$ & Lumbar & & & & & & & $\begin{array}{l}\text { Osteopenia found more in } \\
\text { those with recent diagnosis } \\
\text { than those started on GFD; } \\
\text { one-year GFD was not } \\
\text { enough in many to correct } \\
\text { osteopenia }\end{array}$ \\
\hline (44), 2001 & & & mean age & and $\mathrm{FN}$ & $\mathrm{FN}$ & & & & 27 & 44 & \\
\hline & & & 56 years & & RA & & & & 36 & 32 & \\
\hline $\begin{array}{l}\text { Mora et al } \\
\text { (80), } 2001\end{array}$ & Italy & Longitudinal & $\begin{array}{l}19 \mathrm{CD} \\
211 \text { control, } \\
\text { mean age } \\
14.2 \text { years }\end{array}$ & $\begin{array}{l}\text { LS, } \\
\text { whole } \\
\text { skelton }\end{array}$ & & & & & & & $\begin{array}{l}\text { BMC, bone area and BMD } \\
\text { improved with GFD as well } \\
\text { as bone turnover markers }\end{array}$ \\
\hline $\begin{array}{l}\text { Carvalho et al } \\
\text { (81), } 2003\end{array}$ & Brazil & $\begin{array}{l}\text { Cross- } \\
\text { sectional }\end{array}$ & $\begin{array}{c}30 \mathrm{CD} \text { (children } \\
+ \text { adolescents) } \\
23 \text { control }\end{array}$ & Lumbar & LS & & & & & 38 & $\begin{array}{l}\text { BMD of adolescents lower } \\
\text { than control but no differ- } \\
\text { ence in BMD of children } \\
\text { vs control }\end{array}$ \\
\hline $\begin{array}{l}\text { Kavak et al } \\
(47), 2003\end{array}$ & Turkey & $\begin{array}{l}\text { Prospective } \\
\text { cohort }\end{array}$ & $\begin{array}{c}62 \mathrm{CD} \\
64 \text { control } \\
\text { (children) }\end{array}$ & & & & & & & & $\begin{array}{l}\text { BMD lower in untreated vs } \\
\text { treated and control. } \\
\text { Untreated also had } \\
\text { significantly higher PTH } \\
\text { and lower serum calcium. } \\
\text { GFD improved BMD in } \\
1 \text { year }\end{array}$ \\
\hline $\begin{array}{l}\text { Lewis and Scott } \\
\text { (83), } 2005\end{array}$ & England & Case control & $\begin{array}{c}43 \mathrm{CD} \\
\text { biopsy proven }\end{array}$ & Lumbar & LS & $\begin{array}{c}-0.26,0.22 \\
\text { (women) } \\
-1.16 \text { (men) } \\
0.04 \\
0.22 \\
\text { (women)- } \\
0.43 \text { (men) }\end{array}$ & -0.55 & 5 & 14 & 40 & \\
\hline $\begin{array}{l}\text { Pazianas et al } \\
\text { (84), } 2005\end{array}$ & USA & $\begin{array}{l}\text { Prospective } \\
\text { cohort }\end{array}$ & $\begin{array}{c}24 \mathrm{CD} \\
\text { male } 20 \\
\text { control }\end{array}$ & $\begin{array}{l}\text { Not } \\
\text { stated }\end{array}$ & $\begin{array}{l}\text { LS whole } \\
\text { body } \\
\text { trochan- } \\
\text { ter }\end{array}$ & & & & & & $\begin{array}{l}\text { BMD significantly lower in } \\
\text { treated vs control with } \\
\text { inverse correlation between } \\
\text { PTH and FN or whole body } \\
\text { BMD as well as PTH and } \\
\text { duration of GFD }\end{array}$ \\
\hline $\begin{array}{l}\text { Deressa et al } \\
\text { (85), } 2006\end{array}$ & Norway & Case control & $\begin{array}{l}118 \mathrm{CD}, \\
\text { median age } \\
42.5 \text { years }\end{array}$ & & & & & & & & $\begin{array}{l}\text { BMD significantly reduced } \\
(P<0.001) \text { at all sites }\end{array}$ \\
\hline $\begin{array}{l}\text { Tau et al (24), } \\
2006\end{array}$ & Argentina & $\begin{array}{l}\text { Prospective } \\
\text { longitudinal }\end{array}$ & $\begin{array}{l}24 \mathrm{CD} \text { children, } \\
\text { mean age } \\
4.9 \text { years }\end{array}$ & & & & & & & & $\begin{array}{l}\text { BMC BMD spine, axial BMD } \\
\text { reverted to normal or most in } \\
\text { under } 4 \text { years following GFD }\end{array}$ \\
\hline
\end{tabular}

$\uparrow$ Increase; BMC Bone mineral content; BMI Body mass index; DXA Dual x-ray absorptiometry; F Femur; FN Femoral neck; GFD Gluten-free diet; LS Lumbar spine; PTH Parathyroid hormone; vs Versus 
TABLE 2

Lumbar bone mineral density (BMD) in celiac disease (CD) patients at diagnosis compared with controls

\begin{tabular}{lccccc}
\hline & Age & & & \\
& range, & & \multicolumn{2}{c}{ Lumbar spine BMD, g/cm } & \\
\cline { 3 - 4 } Author (reference), year & years & CD group & Control group & P \\
\hline Kemppainen et al (36), 1999 & $23-69$ & $1.06 \pm 0.19$ & $1.13 \pm 0.16$ & 0.03 \\
Pistorius et al (50), 1995 & $20-70$ & $1.076 \pm 0.186$ & $1.155 \pm 0.143$ & $<0.001$ \\
Mora et al (45), 1998 & $2-20$ & $0.708 \pm 0.034$ & $0.749 \pm 0.017$ & 0.015 \\
Kavak et al (47), 2003 & $2-16$ & $0.447 \pm 0.144$ & $0.537 \pm 0.080$ & 0.006 \\
\hline
\end{tabular}

Data presented as mean \pm SD unless otherwise indicated

at $\mathrm{CD}$ diagnosis are predictive of bone mineralization status in adult patients. Patients with higher PTH levels are more likely to have lower BMD (36-39) and less likely to normalize their BMD after three years on a GFD (37). These data suggest that PTH levels at CD diagnosis may be a useful prognostic factor for bone disease in CD patients.

Several studies also indicate that serum osteocalcin and bonespecific alkaline phosphatase levels correlate negatively with BMD $(18,37,38)$, while in adults, $25(\mathrm{OH}) \mathrm{D}_{3}$ levels correlate positively with $\operatorname{BMD}(18,36,37)$.

Adults who respond to a GFD have lower levels of bone-specific alkaline phosphatase and osteocalcin, and higher levels of $25(\mathrm{OH}) \mathrm{D}_{3}$ than patients with refractory disease or persistent villous atrophy $(17,39)$. Baseline levels of carboxy-terminal propeptide of type I collagen have been reported to correlate best with an increase in BMD following a GFD (18).

Based on these studies, it appears reasonable to measure $25(\mathrm{OH}) \mathrm{D}_{3}$, calcium corrected for albumin and PTH levels in newly diagnosed adult CD patients, to assess the extent of bone loss at diagnosis and to estimate the likely effect of a GFD in restoring bone density.

Other serological markers that correlate with BMD include tTG antibodies and IgA EMA. A study by Agardh et al (40) showed that in women 50 to 64 years of age, high tTG antibody levels $(>17 \mathrm{U} / \mathrm{mL})$ were correlated with lower BMD $\left(0.41 \pm 0.08 \mathrm{~g} / \mathrm{cm}^{2}\right.$ versus $\left.0.44 \pm 0.08 \mathrm{~g} / \mathrm{cm}^{2} ; \mathrm{P}=0.001\right)$, a higher prevalence of osteoporosis $(13.4 \%$ versus $6.5 \% ; \mathrm{P}=0.008)$ and a higher fracture frequency $(32.2 \%$ versus $18.8 \% ; \mathrm{P}=0.009$ ). A study by Duerksen et al (41) confirmed that women who were seropositive for tTG and/or EMA had lower $\mathrm{BMD}$ at all measured sites than the seronegative control group. The prevalence of osteoporosis among seropositive patients was $67.7 \%$ versus $44.8 \%$ for seronegative patients. Recommended cut-off values for commercial tTG kits are $<20 \mathrm{U} / \mathrm{mL}$ (normal), $20 \mathrm{U} / \mathrm{mL}$ to $100 \mathrm{U} / \mathrm{mL}$ (mid-range), and $>100 \mathrm{U} / \mathrm{mL}$ (high). Using these cut-offs and a known $\operatorname{IgA}$ status, the sensitivity and specificity of $\mathrm{tTG}$ as a screening test has been shown to be 0.980 and 0.972 , respectively (42).

A study by Blazina et al (43) compared BMD in children and adolescents who were on a strict GFD with patients who had occasional gluten intake. Compliance with a GFD was monitored by EMA status. Patients who were EMA positive at any time during the study were classified as not strictly compliant, whereas those who were EMA negative throughout the study were classified as strictly compliant. The results showed that $71 \%$ of patients who were EMA positive had total body BMD Z-scores below -1.0 compared with $38 \%$ in the strictly compliant group $(\mathrm{P}=0.03)$. However, it is important to note that calcium intake and vitamin $\mathrm{D}$ levels were below recommendations within both groups. The authors proposed that because BMD is affected both by impaired absorption of calcium and vitamin $\mathrm{D}$ in the bowel, as well as by the presence of inflammatory cytokines and autoantibodies, patients with occasional gluten ingestion remain seropositive and are thus at an increased risk of reduced BMD even if intestinal absorption is not significantly affected.

How common is skeletal disease in CD patients?

BMD: $B M D$ at diagnosis of $C D$ : Studies evaluating the mean BMD at the time of CD diagnosis are summarized in Table 2. The absolute prevalence of osteoporosis/osteopenia in CD patients is unclear due to the
TABLE 3

Mean lumbar bone mineral density (BMD) in celiac disease patients at diagnosis and after one year on a gluten-free diet (GFD)

\begin{tabular}{|c|c|c|c|c|c|}
\hline \multirow[b]{2}{*}{$\begin{array}{l}\text { Author (ref), } \\
\text { year }\end{array}$} & \multirow{2}{*}{$\begin{array}{c}\text { Age } \\
\text { group, } \\
\text { years }\end{array}$} & \multicolumn{2}{|c|}{ Lumbar BMD*, g/cm² } & \multirow{2}{*}{\multicolumn{2}{|c|}{$\begin{array}{c}\text { Increase } \\
\text { after } 1 \text { year, } \\
\% \\
\end{array}$}} \\
\hline & & Basal & $\begin{array}{l}\text { After } 1 \text { year } \\
\text { on GFD }\end{array}$ & & \\
\hline $\begin{array}{l}\text { Kemppainen et } \\
\text { al (36), } 1999\end{array}$ & $23-66$ & $1.07 \pm 0.19$ & $1.11 \pm 0.13$ & $\leq 0.001$ & 3.7 \\
\hline $\begin{array}{l}\text { Ciacci et al } \\
(19), 1997\end{array}$ & $18-68$ & $0.795 \pm 0.177$ & $0.907 \pm 0.180$ & $<0.001$ & 14 \\
\hline $\begin{array}{l}\text { Sategna- } \\
\text { Guidetti et al } \\
(57), 2000\end{array}$ & $19-67$ & $0.886 \pm 0.15$ & $0.933 \pm 0.14$ & $<0.0001$ & 5.3 \\
\hline $\begin{array}{l}\text { Mora et al (45), } \\
1998\end{array}$ & $2-20$ & $0.683 \pm 0.036$ & $0.745 \pm 0.042$ & 0.03 & 9.0 \\
\hline
\end{tabular}

*Data presented as mean \pm SD unless otherwise indicated. GFD has a significant effect on improving BMD and is an important component of managing low BMD in celiac disease patients. ref Reference

small numbers of patients studied and the varied study populations. However, data from two studies involving adult CD patients suggest that approximately one-third have osteoporosis, one-third have osteopenia and one-third have a normal BMD at presentation $(36,44)$.

Low BMD is detected in children and adolescents with newly diagnosed CD (45-47). One study conducted in Edmonton, Alberta, observed lumbar spine BMD Z-scores $\leq-2$ SDs in $16 \%$ of pediatric CD patients, Z-scores below -1 SD but above -2 SDs in 19\%, and a Z-score $\geq-1$ SD in $65 \%$ (48). In another study that assessed bone mineral content (BMC) in children with CD (26), whole body and lumbar spine BMC were identified to be lower in children with CD than in healthy controls by $1.0 \mathrm{~g}$ (lumbar spine) and $38.7 \mathrm{~g}$ (whole body). In 24 children ranging in age from one to 11 years at diagnosis, lumbar spine BMD measurements expressed as Z-scores were reported to be low $(-1.36 \pm 1.20)$ and $17 \%$ had $Z$-scores that were $>2$ SDs below the population mean (25).

The risk of low BMD among newly diagnosed adult CD patients is higher with increased age, lower body mass index and years after menopause $(16,36,44,49-52)$.

Effect of GFD on BMD: Studies evaluating the BMD response to a GFD are summarized in Table 3.

In 2003, the American Gastroenterological Association (53) concluded that, among newly-diagnosed CD patients, osteoporosis was found in 28\% when mesuring the lumbar spine and $15 \%$ when measuring the hip. Adults and children had a similar prevalence of low BMD at diagnosis, but children normalized their BMD after initiation of a GFD $(45,54,55)$. Adults had the greatest increase in BMD (approximately $5 \%$ ) in their first year on a GFD, but remained below average thereafter $(15,56,57)$. Children diagnosed with CD before two years of age, who were on a GFD for at least 24 months, tended to attain greater bone mass than older patients (46). Patients having persistent abnormal small bowel morphology have the lowest BMD (55).

The American Gastroenterological Association proposed broader screening of family members of patients with $\mathrm{CD}$ and those with type 1 diabetes mellitus, Addison disease and other polyglandular diseases because low BMD does not seem to be fully reversible in adults, and because early diagnosis and treatment for asymptomatic CD patients may optimize skeletal health and prevent fracture development.

\section{Fracture risk}

$\mathrm{BMD}$ is only one of the factors associated with increased fracture rates in CD patients. Bone quality, microarchitecture, geometry, bone cell function, mineralization and collagen fibre strength, as well as neuromuscular function, all determine the risk of fracture and bone strength. This was best highlighted in a study by Moreno et al (58), who did not find a significant difference between $\mathrm{T}$-scores and $\mathrm{Z}$-scores of $\mathrm{CD}$ patients with or without fractures. The study found that patients with a classical presentation of CD had a higher fracture risk (47\%) 
compared with controls (15\%) (OR 5.2 [95\% CI 2.8 to 9.8]; $\mathrm{P}<0.0001)$. Fractures in subclinical/silent cases were not different from their controls (20\% versus 14\%; OR 1.7 [95\% CI 0.7 to 4.4]; P not significant). Multivariate analyses did not show any one single characteristic to be highly predictive of fracture risk.

Studies evaluating the risk of fracture in CD patients are conflicting, with some showing no significant increase in fractures $(59,60)$, and others reporting a higher risk $(27,61,62)$. RRs for fractures of any type range from 0.94 (95\% CI -0.71 to 1.24$)$ (46) to 7.0 (63), and for hip fractures, range from $0.66(95 \% \mathrm{CI}-0.05$ to 9.50$)(64)$ to $1.9(95 \%$ CI -1.2-3.02) (65).

In the largest study to date on the incidence of fractures in CD population, Ludvigsson et al (63) used a Swedish National Registry to estimate the risk of hip fractures and fractures of any type in a large general population cohort study. The hazard ratio (HR) for a hip fracture was 2.1 (95\% CI 1.8 to 2.4) in adults, and 2.6 (95\% CI 1.1 to 6.2 ) in children. It is important to note that hip fractures are rare in children; the increased HR was based on six hip fractures per 100,000 patient years for pediatric CD patients compared with two per 100,000 patient years among reference individuals. The HR for fractures of any type for all ages was 1.4 (95\% CI 1.3 to 1.5$)$, with a marginal statistical significance of $\mathrm{P}=0.052$. Although a GFD allows for improvement in $\mathrm{BMD}$, adult patients do not regain their peak bone mass and their BMD remains lower than in healthy controls (70). As a result, CD patients remain at an increased risk of fractures 20 years after diagnosis even if they adhere to a GFD (63).

The studies above conclude that both adult and pediatric CD patients have a significant increase in the risk of hip fractures and fractures of any other type, regardless of whether the fracture occurred before or after the diagnosis of CD. The duration after diagnosis of CD did not notably influence the risk of hip fractures and, therefore, no evidence was found in the study by Ludvigsson et al (63) that a GFD lowers the risk of hip fractures. The positive association between CD and hip fractures was independent of sex and age (63). The study also showed increased risk of subsequent hip fractures in individuals with CD diagnosed in childhood (HR 2.6 [95\% CI -1.1 to 6.2]).

Moreno et al (58) showed that peripheral fractures are more common in adult CD patients than in age- and sex-matched controls. CD patients with a classic clinical course (eg, chronic diarrhea and malabsorption) had a significantly higher prevalence of fractures in the peripheral skeleton (OR -5.2 [95\% CI -2.8 to 9.8) compared with patients with subclinical or silent $\mathrm{CD}$, and to age- and sex-matched controls. Vazquez et al (62) also showed that adult CD patients had a higher prevalence of peripheral fractures (25\%) compared with sex- and agematched controls $(8 \%)$. Other studies $(64,67,68)$ reported trends toward an increased fracture risk that were not statistically significant.

A recent systematic review of case control and cohort studies (64) reported that the fracture risk was $43 \%$ greater in adult CD patients than in controls (OR 1.43 [95\% CI -1.15 to 1.78]), although there was significant, unexplained, quantitative and qualitative heterogeneity among the studies, possibly attributable to differences in subject selection, small sample sizes and differences in methodologies used to assess and define fractures, and lack of information on disease duration and therapeutic interventions. Nonetheless, the results of the systematic review, supplemented by the results of two case control studies (Table 4) confirm that adult CD patients have a significantly increased risk of fracture. Additional research is needed to identify which $\mathrm{CD}$ patients are at a higher risk of fracture so that clinicians can implement screening, risk stratification and treatment strategies more effectively.

\section{Who should undergo BMD testing?}

Based on the available data, there is no indication to perform a BMD test in the pediatric age group if they are compliant with a GFD because data confirm full recovery. The International Society for Clinical Densitometry guidelines do not include CD as an indication to perform a DXA scan on children and adolescents (69). On the other hand, symptomatic adults with classic malabsorption (weight loss, diarrhea, etc) should have their BMD tested at diagnosis and ensure that malabsorption of calcium, phosphate and vitamin D are corrected. The asymptomatic/silent group represent a 'grey zone' with conflicting data and no consensus, but it would seem prudent to treat them with a GFD and perform a DXA scan one year later when the need for further management can be assessed.

The recent British guidelines (70) recommend that BMD testing be completed in all patients at the time of diagnosis in recognition of the potential impact of chronic malabsorption.

Compston et al (67) suggest BMD assessment be restricted to the minority of individuals in whom short-term fracture risk (five to 10 years) is probably high. In adult CD patients, risk factors may include nonadherence to a GFD, failure to respond to a GFD, corticosteroid treatment, untreated hypogonadism, old age, low body mass index and previous fragility fractures, as well as menstrual irregularity and subclinical hypogonadism in premenopausal women, unexplained iron deficiency anemia and low vitamin D status (indicated by low vitamin D levels and/or low $24 \mathrm{~h}$ urinary calcium). Based on this, Corrazza et al (71) proposed DXA assessment in peri- and postmenopausal women with $\mathrm{CD}$ and male $\mathrm{CD}$ patients $>50$ years of age.

A repeat DXA scan after one year on a GFD is recommended in the presence of osteoporosis/osteopenia at diagnosis $(13,15,16,57)$. In the presence of normal BMD at diagnosis, follow-up may be after two to three years on a GFD, based on other clinical risk factors and response to therapy.

The WHO has developed an absolute fracture risk assessment tool ('FRAX') to estimate the 10-year fracture risk in all adults, which is based on the integration of femoral neck bone density, age and other important clinical risk factors (66). Given that one of the risk factors is chronic malabsorption, use of the FRAX tool would be reasonable for CD patients.

\section{Gaps and limitations with future directions}

In summary, although there is agreement that adult $\mathrm{CD}$ patients have an increased fracture risk, there are important knowledge gaps regarding the prevalence of fragility fracture and relevant risk factors. Prospective population-based fracture data with small bowel biopsy follow-up to clinical presentation and GFD compliance will be very informative. Prevention of osteoporotic fractures should be the main aim when addressing bone health in the adult CD population; restoration of normal bone metabolism, to achieve optimal peak bone mass at the end of puberty, should be the main aim for pediatric CD patients.

Data on management options, other than GFD, for low BMD in $\mathrm{CD}$ patients are limited. Supplementation of calcium and vitamin D has been recommended in some studies but not others, and the role of antiresorptive medications on BMD and fracture risk in CD patients is not known $(70,71)$. There is also no agreement regarding the BMD threshold for treatment in $\mathrm{CD}$ patients or whether a T-score or Z-score should be used in adult CD patients (70); in this context, the FRAX tool may be more useful for determining the fracture risk and appropriate management. In pediatric $\mathrm{CD}$ patients, the only meaningful value is a $\mathrm{BMD} Z$-score to compare unaffected age- and sex-matched populations.

\section{RECOMMENDATIONS FOR DIAGNOSIS, FOLLOW-UP AND TREATMENT OF PATIENTS WITH CD WITH REGARD TO SKELETAL HEALTH \\ Indications for BMD testing}

1. In adults with classic $\mathrm{CD}, \mathrm{BMD}$ should be evaluated following the diagnosis of CD. (Level I)

2. In adults with asymptomatic or silent $\mathrm{CD}, \mathrm{BMD}$ should be evaluated after one year on a GFD. (Level I)

In the absence of other risk factors, the fracture risk is probably less than in patients with classic CD, and it may not be significantly higher than in the general population.

3. In adults with asymptomatic or silent $\mathrm{CD}$, early BMD testing $<1$ year after diagnosis, may be considered if there are other risk factors for low BMD such as the following:

a) Peri- or postmenopausal women. (Level I)

b) Men older than 50 years of age. (Level I)

c) History of fragility fracture. (Level I) 
TABLE 4

Risk of fractures in celiac disease (CD)

\begin{tabular}{|c|c|c|c|c|c|c|}
\hline $\begin{array}{l}\text { Author (ref), } \\
\text { year }\end{array}$ & Country & $\begin{array}{l}\text { Study type, fracture } \\
\text { ascertainment }\end{array}$ & Participants & Outcomes & \multicolumn{2}{|l|}{ Risk estimates (95\% Cl) } \\
\hline $\begin{array}{l}\text { Vazquez et al } \\
\text { (62), } 2000\end{array}$ & Argentina & $\begin{array}{l}\text { Case control, } \\
\text { interview }\end{array}$ & $\begin{array}{l}C D, n=165 \text {, biopsy proven } \\
\text { Malabsorption clinic } \\
\text { Control, } n=165\end{array}$ & $\begin{array}{l}\text { Peripheral fractures } \\
\text { Spine }\end{array}$ & $\begin{array}{l}\text { OR } 3.5 \text { (1.8-7.2), } \\
2.8(0.7-1.150)\end{array}$ & \\
\hline $\begin{array}{l}\text { Fickling et al } \\
\text { (59), } 2001\end{array}$ & $\begin{array}{l}\text { United } \\
\text { Kingdom }\end{array}$ & $\begin{array}{l}\text { Case control, } \\
\text { interview }\end{array}$ & $\begin{array}{l}C D, n=75 \\
\text { Control, } n=75\end{array}$ & $\begin{array}{l}\text { Previous fractures } \\
21 \% \text { vs } 3 \%\end{array}$ & RR 7.0 & \\
\hline $\begin{array}{l}\text { Thomason et al } \\
\text { (60), } 2003\end{array}$ & $\begin{array}{l}\text { United } \\
\text { Kingdom }\end{array}$ & $\begin{array}{l}\text { Case control, } \\
\text { self-report data }\end{array}$ & $\begin{array}{l}C D, n=244 \text { biopsy proven } \\
\text { Control, } n=166 \\
\text { OR adjusted for age, sex }\end{array}$ & $\begin{array}{l}\text { Low trauma } \\
\text { Any fracture } \\
\text { Wrist fracture } \\
\text { Before CD diagnosis }\end{array}$ & $\begin{array}{l}\text { OR } 1.0(0.68-1.02) \\
1.21(0.66-2.25) \\
1.16(0.65-2.10) \\
1.24(0.65-2.39)\end{array}$ & \\
\hline $\begin{array}{l}\text { Vestergaard et al } \\
\text { (86), } 2002\end{array}$ & Denmark & $\begin{array}{l}\text { Retrospective cohort, } \\
\text { administrative } \\
\text { databases }\end{array}$ & $\begin{array}{l}C D, n=7774 \text { person years } \\
\text { Control, } n=23,316 \text { person } \\
\text { years }\end{array}$ & $\begin{array}{l}\text { All fractures } \\
\text { Spine, rib, pelvis }\end{array}$ & $\begin{array}{l}\text { RR } 0.94(0.71-1.24) \\
2.14(0.7-6.57) \text { pre glut } \\
1.07(0.39-2.95) \text { post gl }\end{array}$ & $\begin{array}{l}\text {-free diet } \\
\text { en-free diet }\end{array}$ \\
\hline $\begin{array}{l}\text { West et al (65), } \\
2003\end{array}$ & $\begin{array}{l}\text { United } \\
\text { Kingdom }\end{array}$ & $\begin{array}{l}\text { Retrospective cohort, } \\
\text { administrative } \\
\text { databases }\end{array}$ & $\begin{array}{l}C D, n=4732 \\
\text { Control, } n=23,620 \\
\text { No biopsy data }\end{array}$ & $\begin{array}{l}\text { All fractures } \\
\text { Hip fractures } \\
\text { Ulna/radius }\end{array}$ & $\begin{array}{l}\text { HR } 1.3(1.16-1.46) \\
\text { HR } 1.9(1.2-3.02) \\
\text { HR } 1.77(1.35-2.34)\end{array}$ & \\
\hline $\begin{array}{l}\text { Moreno et al } \\
(58), 2004\end{array}$ & Argentina & $\begin{array}{l}\text { Cross-sectional, } \\
\text { case control }\end{array}$ & $\begin{array}{l}C D, n=148 \\
\text { Symptomatic, } n=78(53 \%) \\
\text { Silent, } n=17(11 \%) \\
\text { Subclinical, } n=53(36 \%) \\
\text { Control, } n=296 \\
\text { Age/sex-matched } \\
\text { Biopsy proven }\end{array}$ & All fractures & $\begin{array}{l}\text { Symptomatic group } 47 \% \\
\text { OR } 5.2(2.8-9.8) \\
\text { Subclinical group } 20 \% \text { f } \\
\text { OR } 1.7(0.7-4.4) \\
\text { Symptomatic group vs s } \\
\text { OR } 3.6 \text { (1.7-7.5) } \\
\text { No difference among dif } \\
\text { premenopausally } \\
\text { Original data }\end{array}$ & $\begin{array}{l}\text { ractures vs control } \\
\text { ctures vs control } \\
\text { oclinical group } \\
\text { rent group } \\
\text { Corrected for } \\
\text { height, weight }\end{array}$ \\
\hline $\begin{array}{l}\text { Davie et al (87), } \\
2005\end{array}$ & $\begin{array}{l}\text { United } \\
\text { Kingdom }\end{array}$ & $\begin{array}{l}\text { Case control, } \\
\text { questionnaire-based } \\
\text { fractures by recall } \\
\text { postmenopausal } \\
\text { women }\end{array}$ & $\begin{array}{l}C D, n=383 \\
90.3 \% \text { biopsy proven } \\
\text { Control, } n=445\end{array}$ & $\begin{array}{l}\text { Any fracture } \\
\text { Any fracture after } 50 \text { yrs } \\
\text { Any wrist fracture } \\
\text { Any wrist fracture after } 50 \text { yrs } \\
\text { Any nonwrist fracture } \\
\text { Any nonwrist fracture after } 50 \text { yrs } \\
\text { More than one fracture }\end{array}$ & $\begin{array}{l}\text { OR } 1.51(1.13-2.02) \\
\text { OR } 2.20(1.49-3.25) \\
\text { OR } 1.65(1.12-2.44) \\
\text { OR } 2.17(1.22-3.87) \\
\text { OR } 1.66(1.21-2.27) \\
\text { OR } 2.34(1.51-3.63) \\
\text { OR } 2.96(1.81-4.83)\end{array}$ & $\begin{array}{l}1.55(1.11-2.18) \\
2.38(1.52-3.75) \\
1.45(0.92-2.29) \\
1.80(0.93-3.49) \\
1.86(1.29-2.68) \\
2.73(1.64-4.54) \\
3.36(1.94-5.83)\end{array}$ \\
\hline $\begin{array}{l}\text { Ludvigsson et al } \\
\text { (63), } 2007\end{array}$ & Sweden & $\begin{array}{l}\text { Population-based } \\
\text { cohort }\end{array}$ & $\begin{array}{l}C D, n=13,724 \\
\text { Control, } n=65,627\end{array}$ & $\begin{array}{l}\text { First hip fracture } \\
\text { *First year excluded } \\
\text { Any CD } \\
0-15 \text { yrs } \\
\geq 16 \text { yrs } \\
\text { Males } \\
\text { Females } \\
\text { * First year included } \\
\text { Any fracture } \\
\text { *First year excluded } \\
\text { Any CD } \\
\text { 0-15 yrs } \\
\geq 16 \text { yrs } \\
\text { Males } \\
\text { Females } \\
\text { *First year included }\end{array}$ & $\begin{array}{l}\text { HR } 2.1(1.8-2.4) \\
\text { HR } 2.6(1.1-6.2) \\
\text { HR } 2.1(1.8-2.4) \\
\text { HR } 2.2(1.7-2.9) \\
\text { HR } 2.0(1.7-2.4) \\
\text { HR } 2.2(2.0-2.5)\end{array}$ & \\
\hline $\begin{array}{l}\text { Jafri et al (88), } \\
2007\end{array}$ & $\begin{array}{l}\text { United } \\
\text { States }\end{array}$ & $\begin{array}{l}\text { Population-based } \\
\text { cohort, } \\
\text { administrative } \\
\text { databases }\end{array}$ & $\begin{array}{l}\text { CD, } n=83 \\
\text { Control, } n=166\end{array}$ & $\begin{array}{l}\text { Any fracture } \\
\text { Peripheral } \\
\text { Axial } \\
\text { Osteoporotic }\end{array}$ & $\begin{array}{l}\text { OR } 2.0(1.0-3.9) \\
\text { OR } 2.0(1.0-3.8) \\
\text { OR } 1.7(0.7-4.1) \\
\text { OR } 8.0(0.9-72)\end{array}$ & \\
\hline
\end{tabular}

Data analysis showing fracture risk in CD. The analysis in this table was first performed in 2008, before the systematic review and meta-analysis by Olmos et al (65) was published. Thus, much of the analysis in this table is similar to the analysis in that study. However, this table has been re-updated to include new data that became available after the Olmos et al (65) systematic review. The Olmos et al (65) article, which includes the first eight studies in this table, showed that fracture risk was 43\% greater in adult CD patients than in controls (OR 1.43 [95\% Cl 1.15 to 1.78]), with significant, unexplained, quantitative and qualitative heterogeneity among the studies, possibly attributable to differences in subject selection, small sample sizes, differences in methodologies used to assess and define fractures, and lack of information on disease duration and therapeutic interventions. ref Reference; vs Versus; yrs Years of age 
d) Unexplained iron deficiency anemia. (Level III)

e) Vitamin D deficiency/insufficiency. (Level II)

f) High titres for CD serological markers. (Level I)

g) In pediatric CD patients, BMD testing should be offered one year after diagnosis if patients do not self-report strict adherence to a GFD. (Level I)

4. In adult CD patients, repeat DXA (or first time DXA) testing should be offered to all groups at menopause and men after 50 years of age. (Level II)

5. The FRAX tool will be useful to estimate fracture risk and plan management accordingly. (Level II)

\section{Indications for BMD follow-up in adults}

1. In the presence of osteopenia/osteoporosis at diagnosis, follow-up BMD should be offered after one year on a GFD. (Level I)

2. In the presence of a normal BMD at diagnosis, follow-up should be after two years on a GFD, particularly if the patient remains symptomatic or is nonadherent to the diet. (Level III)

\section{Indications for biochemical assessment and follow-up}

1. In adult $C D$ patients, biochemical profile for the assessment of skeletal mineralization should be offered at the time of CD diagnosis in adults, including serum calcium, albumin, $25(\mathrm{OH}) \mathrm{D}_{3}$ and PTH levels. (Level II)

2. In adult $\mathrm{CD}$ patients, routine $24 \mathrm{~h}$ urine calcium testing is not recommended. (Level III)

Comment: Urinary calcium testing may be helpful to assess calcium absorption; however, there are few data to support this recommendation and there other factors, including renal function, that will affect urinary calcium excretion.

3. Biochemical profile could be repeated every six months until normalization. (Level III)

4. Biochemical markers of bone turnover (eg, osteocalcin, procollagen type $1 \mathrm{~N}$-terminal propeptide, urinary collagen

\section{REFERENCES}

1. Green PHR, Cellier C. Celiac disease. N Engl J Med 2007;357:1731-43.

2. Tomasini A, Not T, Kren V, et al. Mass screening for celiac disease using antihuman transglutaminase antibody assay. Arch Dis Child 2004;89:15

3. Ferguson A, Arranz E, O'Mahony S. Clinical and pathological spectrum of coeliac disease: Active, silent, latent and potential. Gut 1993;34:150-1.

4. Kelly C, Dennis M. UpToDate. Patient Information: Celiac Disease in Adults. <www.uptodate.com/contents/patient-information-celiacdisease-in-adults> (Accessed December 29, 2011).

5. Dubé C, Rostom A, Sy R, et al. The prevalence of celiac disease in average-risk and at-risk Western European populations:

A systematic review. Gastroenterology 2005;128:S57-67.

6. Fasano A, Berti I, Gerarduzzi T, et al. Prevalence of celiac disease in at-risk and not-at-risk groups in United States: A large multicenter study. Arch Inter Med 2003;163:286-92.

7. Hawkes ND, Swift GL, Smith PM, Jenkins HR. Incidence and presentation of coeliac disease in South Glamorgan. Eur J Gastroenterol Hepatol 2000;12:345-9.

8. Kolho KL, Farkkila MA, Savilahti E. Undiagnosed coeliac disease is common in Finnish adults. Scand J Gastroenterol 1998;33:1280-3.

9. Volta U, Bellentani S, Bianchi FB, et al. High prevalence of celiac disease in Italian general population. Dig Dis Sci 2001;46:1500-5.

10. Bennett TI, Hunter D, Vaugham JM. Idiopathic steatorrhea. A nutritional disturbance associated with tetany, osteomalacia and anaemia. Q J Med 1932;1:603-77.

11. Holms WH, Starr P. A nutritional disturbance in adults resembling coeliac disease and sprue: Emaciation, anemia, tetany, chronic diarrhea and malabsorption of fat. JAMA 1929; 92:975-80.

12. Salvesen HA, Boe J. Osteomalacia in sprue. Acta M Scan 1953;146:290-9. crosslinks [NTx]) should be reserved for research studies. (Level III)

5. Serological CD markers (IgA, tTGA, IgA EMA) can be used as indicators of the severity of CD-related mucosal damage. (Level I).

Comment: The severity of mucosal damage appears to be a predictor of malabsorption and, hence, of the risk of low bone density. Cytokine excess associated with mucosal damage (increased IL-6, decreased IL-12 and IL-18 levels) also contributes to bone loss through increased osteoclast formation, function and survival.

6. Serological CD markers may be used as a screening tool in asymptomatic/silent CD patients to identify those who may benefit from an early DXA to diagnose low bone mass. (Level II)

\section{Treatment}

1. GFD adherence is the treatment of choice for normalization of BMD in CD patients. (Level I)

2. Pharmacological intervention with antiresorptive medications can be used to treat osteoporosis in postmenopausal adult CD patients after ensuring that adequate calcium and vitamin D supplementation has been provided. (Level III)

Comment: Other strategies used in the management of postmenopausal osteoporosis may be considered but there are no longitudinal data to support this practice in CD patients.

\section{APPENDIX 1: LEVELS OF EVIDENCE ADAPTED FROM THE CANADIAN TASK FORCE ON PREVENTIVE HEALTHCARE (20)}

Levels of evidence

Level I: At least one properly conducted randomized controlled trial, systematic review, or meta-analysis.

Level II: Other comparison trials, non-randomized, cohort, casecontrol, or epidemiologic studies, and preferably more than one study.

Level III: Expert opinion or consensus statement.

13. Corazza GR, Di Sario A, Cecchetti L, et al. Influence of pattern of clinical presentation and of gluten-free diet on bone mass and metabolism in adult coeliac disease. Bone 1996;18:525-30.

14. Mazure R, Vazquez $\mathrm{H}$, Gonzalez D, et al. Bone mineral affection in asymptomatic adult patients with celiac disease. Am J Gastroenterol 1994;89:2130-4

15. McFarlane XA, Bhalla AK, Robertson DA. Effect of gluten-free diet on osteopenia in adults with newly diagnosed coeliac disease. Gut 1996;39:180-4.

16. Valdimarsson T, Lofman O, Toss G, Strom M. Reversal of osteopenia with diet in adult coeliac disease. Gut 1996;38:322-7.

17. Mautalen C, Gonzalez D, Mazure R, et al. Effect of treatment on bone mass, mineral metabolism and body composition in untreated celiac disease patients. Am J Gastroenterol 1997;92:313-8.

18. Corazza GR, Di Stefano M, Jorizzo RA, Cecchetti L, Minguzzi L, Gasbarrini G. Propeptide of type 1 procollagen is predictive of post-treatment bone mass gain in adult celiac disease. Gastroenterology 1997;113:67-71.

19. Ciacci C, Maurelli L, Klain M, et al. Effects of dietary treatment on bone mineral density in adults with celiac disease: Factors predicting response. Am J Gastroenterol 1997;92:992-6.

20. Canadian Family Physician. Guidelines for Articles. <www.cfp.ca/ site/Authors/Guidelines.xhtml> (Accessed August 22, 2011).

21. Selby P, Davies M, Adams J, Mawer B. Bone Loss in celiac disease is related to secondary hyperparathyroidism. J Bone Miner Res 1999;14:652-7.

22. Corazza GR, Di Sario A, Cecchetti L, et al. Bone mass and metabolism in patients with celiac disease. Gastroenterology 1995;109:122-8.

23. Keaveny AP, Freaney R, McKenna MJ, Masterson J, O'Donaghue DP. Bone remodeling indices and secondary hyperparathyroidism in coeliac disease. Am J Gastroenterol 1996;91:1226-31. 
24. Tau C, Mautalen C, De Rosa S, Roca A, Valenzuela X. Bone mineral density in children with celiac disease. Effect of a gluten free diet. Eur J Clin Nutr 2006;60:358-63.

25. Hartman C, Hino B, Lerner A, et al. Bone quantitative ultrasound and bone mineral density in children with celiac disease. J Pediatr Gastroenterol Nutr 2004;39:504-10.

26. Barera G, Beccio S, Proverbio MC, Mora S. Longitudinal changes of bone metabolism and bone mineral content in children with celiac disease during consumption of a gluten free diet. Am J Clin Nutr 2004;79:148-54.

27. Mora S, Barera G, Beccio S, et al. Bone density and bone metabolism are normal after long term gluten free diet in young celiac patients. Am J Gastroenterol 1999;94:398-403.

28. Kontakou M, Przemioslo RT, Sturgess RP, Limb AG, Ciclitira PJ. Expression of tumor necrosis factor-alpha, interleukin-6, and interlukin-2 mRNA in the jejunum of patients with coeliac disease. Scand J Gastroenterol 1995;30:456-63.

29. Fornari MC, Pedreira S, Niveloni S, et al. Pre- and post-treatment serum levels of cytokines, IL-1 beta, IL-6 and IL-1 receptor antagonist in celiac disease: Are they related to the associated osteopenia? Am J Gastroenterol 1998;93:413-8.

30. Di Stefano M, Sciarra G, Jorizzo RA, et al. Local and gonadal factors in the pathogenesis of celiac bone loss. Ital J Gastroenterol Hepatol 1997;29(Suppl 2):31.

31. Taranta A, Fortunati D, Longo M, et al. Imbalance of osteoclastogenesis-regulating factors in patients with celiac disease. J Bone Miner Res 2004;19:1112-21.

32. Horwood NJ, Elliot J, Martin TJ, Gillespie MT. IL-12 alone and in synergy with IL-18 inhibits osteoclast formation in vitro. J Immunol 2001;15:4915-21.

33. Yamada N, Niwa S, Tsujimura T, et al. Interleukin 18 and interleukin 12 synergistically inhibit osteoclastic bone-resorbing activity. Bone 2002;30:901-8.

34. Smecuol E, Maurino E, Vazquez H, et al. Gynaecological and obstetric disorders in coeliac disease: Frequent clinical onset during pregnancy or the puerperium. Eur J Gastroenterol Hepatol 1996;8:63-89.

35. Riggs BL, Melton LJ. Osteoporosis: Etiology, Diagnosis and Management. New York: Raven Press, 1988.

36. Kemppainen T, Kroger H, Janatuinen E, et al. Osteoporosis in adult patients with celiac disease. Bone 1999;24:249-55.

37. Valdimarsson T, Toss G, Lofman O, Strom M. Three years' follow-up of bone density in adult coeliac disease: Significance of secondary hyperparathyroidism. Scand J Gastroenterol 2000;3:274-80.

38. West J, Logan RF, Hill PG, Khaw KT. The iceberg of celiac disease: What is below the waterline? Clin Gastroenterol Hepatol 2007;5:59-62.

39. Maki M, Mustalahti K, Kokoonen J, et al. Prevalence of celiac disease among children in Finland. N Engl J Med 2003;348:2517-24.

40. Agardh D, Bjorck S, Agardh CD, Lidfeldt J. Coeliac disease-specific tissue transglutaminase autoantibodies are associated with osteoporosis and related fractures in middle-aged women. Scand J Gastroenterol 2009;44:571-8.

41. Duerksen DR, Leslie WD. Positive celiac disease serology and reduced bone mineral density in adult women. Can J Gastroenterol 2010:24:103-7.

42. Barker C, Mitton C, Jevon G, Mock T. Can tissue transglutaminase antibody titers replace small-bowel biopsy to diagnose celiac disease in select pediatric populations? Pediatrics 2005;115:1341-6.

43. Blazina S, Bratanic N, Sampa AS, Blagus R, Orel R. Bone mineral density and importance of strict gluten-free diet in children and adolescents with celiac disease. Bone 2010;47:598-603.

44. Meyer D, Stavropolous S, Diamond B, Shane E, Green PHR. Osteoporosis in a North American adult population with celiac disease. Am J Gastroenterol 2001;96:112-9.

45. Mora S, Barera G, Ricotti A, Weber G, Bianchi C, Chiumello G. Reversal of low bone density with a gluten-free diet in children and adolescents with celiac disease. Am J Clin Nutr 1998;67:477-81.

46. Scotta MS, Salvatorre S, Salvatoni A, et al. Bone mineralization and body composition in young patients with celiac disease. Am J Gastroenterol 1997;92:1131-4.

47. Kavak US, Yuce A, Kocak N, et al. Bone mineral density in children with untreated and treated celiac disease. J Pediatr Gastroenterol Nutr 2003;37:434-6.

48. Turner J, Pellerin G, Mager D. Prevalence of metabolic bone disease in children with celiac disease is independent of symptoms at diagnosis. J Pediatr Gastroenterol Nutr 2009;49:589-93.

49. Valdimarsson T, Toss G, Lofman O, Strom M. Bone mineral density in coeliac disease. Scand J Gastroenterol 1994;29:457-61.
50. Pistorius LR, Sweidan WH, Purdie DW, et al. Coeliac disease and bone mineral density in adult female patients. Gut 1995;37:639-42.

51. McFarlane XA, Bhalla AK, Reeves DE, Morgan LM, Robertson DA. Osteoporosis in treated adult coeliac disease. Gut 1995;36:710-4.

52. Di Stefano M, Veneto G, Corrao G, Corazza GR. Role of lifestyle factors in the pathogenesis of osteopenia in adult coeliac disease: A multivariate analysis. Eur J Gastroenterol Hepatol 2000;12:1195-9.

53. Bernstein CN, Leslie WD, Leboff MS. AGA technical review on osteoporosis in gastrointestinal diseases. Gastroenterology 2003;124:795-841.

54. Mora S, Weber G, Barera G, et al. Effect of gluten-free diet on bone mineral content in growing patients with celiac disease. Am J Clin Nutr 1993;57:224-8.

55. Walters JR, Banks LM, Butcher GP, Fowler CR. Detection of low bone mineral density by dual energy $\mathrm{X}$-ray absorptiometry in unsuspected suboptimally treated coeliac disease. Gut 1995;37:220-4.

56. Kemppainen T, Kroger H, Janatuinen E, et al. Bone recovery after a gluten-free diet: A 5-year follow-up study. Bone 1999;25:355-60.

57. Sategna-Guidetti C, Grosso SB, Grosso S, et al. The effects of 1 -year gluten withdrawal on bone mass, bone metabolism and nutritional status in newly-diagnosed adult coeliac disease patients. Aliment Pharmacol Ther 2000;14:35-43.

58. Moreno ML, Vazquez H, Mazure R, et al. Stratification of bone fracture risk in patients with celiac disease. Clin Gastroenterol Hepatol 2004;2:127-34.

59. Fickling WE, McFarlane XA, Bhalla AK, Robertson DA. The clinical impact of metabolic bone disease in coeliac disease. Postgrad Med J 2001;77:33-6.

60. Thomason K, West J, Logan RF, Coupland C, Holmes GK. Fracture experience of patients with coeliac disease: A population-based survey. Gut 2003;52:518-22.

61. Rostami K, Mulder CJ, Were JM, et al. High prevalence of celiac disease in apparently healthy blood donors suggests a high prevalence of undiagnosed celiac disease in the Dutch population. Scand J Gastroenterol 1999;34:276-9.

62. Vazquez H, Mazure R, Gonzalez D, et al. Risk of fractures in celiac disease patients: A cross-sectional, case-control study. Am J Gastroenterol 2000;95:183-9.

63. Ludvigsson JF, Michaelsson K, Ekbom A, Montgomery SM. Coeliac disease and the risk of fractures - a general population-based cohort study. Aliment Pharmacol Ther 2007;25:273-85.

64. Olmos M, Antelo M, Vazquez H, Smecuol E, Maurino E, Bai JC. Systematic review and meta-analysis of observational studies on the prevalence of fractures in coeliac disease. Dig Liver Dis 2008;40:46-53.

65. West J, Logan RF, Card TR, Smith C, Hubbard R. Fracture risk in people with celiac disease: A population-based cohort study. Gastroenterology 2003;125:429-36.

66. Kanis JA, Burlet N, Cooper C, et al. European guidance for the diagnosis and management of osteoporosis in postmenopausal women. Osteoporosis Int 2008;19:399-428.

67. Compston J. Is fracture risk increased in patients with coeliac disease? Gut 2003;52:459-60.

68. Molteni N, Caraceni MP, Bardella MT, Ortolani S, Gandolini GG, Bianchi P. Bone mineral density in adult celiac patients and the effect of gluten-free diet from childhood. Am J Gastroenterol 1990;85:51-3.

69. The International Society for Clinical Densitometry. Official Positions Text. <www.iscd.org/Visitors/positions/ OfficialPositionsText.cfm> (Accessed September 5, 2011).

70. Scott EM, Gaywood I, Scott BB. Guidelines for osteoporosis in coeliac disease and inflammatory bowel disease. Gut 2000;46:1-8.

71. Corazza GR, Di Stefano M, Maurino E, Bai JC. Bones in coeliac disease: Diagnosis and treatment. Best Pract Res Clin Gastroenterol 2005;19:453-65.

72. Gonzalez D, Mazure R, Mautalen C, Vazquez H, Bai J. Body composition and bone mineral density in untreated and treated patients with celiac disease. Bone 1995;16:231-4.

73. Leiva L, Burrows R, Rios G, et al. Bone mass in celiac patients. Arch Latinoam Nutr 1996;46:128-31.

74. Rea F, Polito C, Marotta A, et al. Restoration of body composition in celiac children after one year of gluten-free diet. J Pediatr Gastroenterol Nutr 1996;23:408-12.

75. Bai JC, Gonzalez D, Mautalen C, et al. Long-term effect of gluten restriction on bone mineral density of patients with coeliac disease. Aliment Pharmacol Ther 1997;11:157-64. 
76. Di Stefano M, Jorizzo RA, Veneto G, Cecchtti L, Gasbarrini G, Corazza GR. Bone mass and metabolism in dermatitis herpetiformis. Dig Dis Sci 1999;44:2139-43.

77. Valdimarsson T, Arnqvist HJ, Toss G, Jarnerot G, Nystrom F, Strom M. Low circulating insulin-like growth factor I in coeliac disease and its relation to bone mineral density. Scand J Gastroenterol 1999;9:904-8.

78. Bardella MT, Fredella C, Prampolini L, Molteni N, Giunta AM, Bianchi PA. Body composition and dietary intakes in adult celiac disease patients consuming a strict gluten-free diet. Am J Clin Nutr 2000;72:937-9.

79. Kalayci AG, Kansu A, Girgin N, Kucuk O, Aras G. Bone mineral density and importance of a gluten-free diet in patients with celiac disease in childhood. Pediatrics 2001;108:E89.

80. Mora S, Barera G, Beccio S, et al. A prospective, longitudinal study of the long-term effect of treatment on bone density in children with celiac disease. J Pediatr 2001;139:516-21.

81. Carvalho CN, Sdepanian VL, de Morais MB, Fagundes Neto U. Celiac disease under treatment: Evaluation of bone mineral density. Rio J 2003;79:303-8.

82. Barera G, Beccio S, Proverbio MC, Mora S. Longitudinal changes in bone metabolism and bone mineral content in children with celiac disease during consumption of a gluten-free diet. Am J Clin Nutr 2004;79:148-54.
83. Lewis NR, Scott BB. Should patients with coeliac disease have their bone mineral density measured? Eur J Gastroenterol Hepatol 2005; 17:1065-70.

84. Pazianas M, Butcher GP, Subhani JM, et al. Calcium absorption and bone mineral density in celiacs after long term treatment with gluten-free diet and adequate calcium intake. Osteoporosis Int 2005; 16:56-63.

85. Deressa E, Wammer AC, Falch JA, Jahnsen J. Bone metabolism in patients with newly diagnosed celiac disease.Tidsskr Nor Laegeforen 2006;126:1201-4.

86. Vestergaard P, Mosekilde L. Fracture risk in patients with celiac disease, Crohn's disease, and ulcerative colitis: A nationwide follow-up study of 16,416 patients in Denmark. Am J Epidemiol 2002;156:1-10.

87. Davie MW, Gaywood I, George E et al. Excess non-spine fractures in women over 50 years with celiac disease: A cross-sectional, questionnaire-based study. Osteoporos Int 2005;16:1150-5.

88. Jafri MR, Nordstrom CW, Murray JA, et al. Long-term fracture risk in patients with celiac disease: A population-based study in Olmsted County, Minnesota. Dig Dis Sci 2007;53:964-71. 


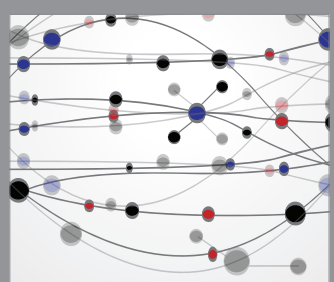

The Scientific World Journal
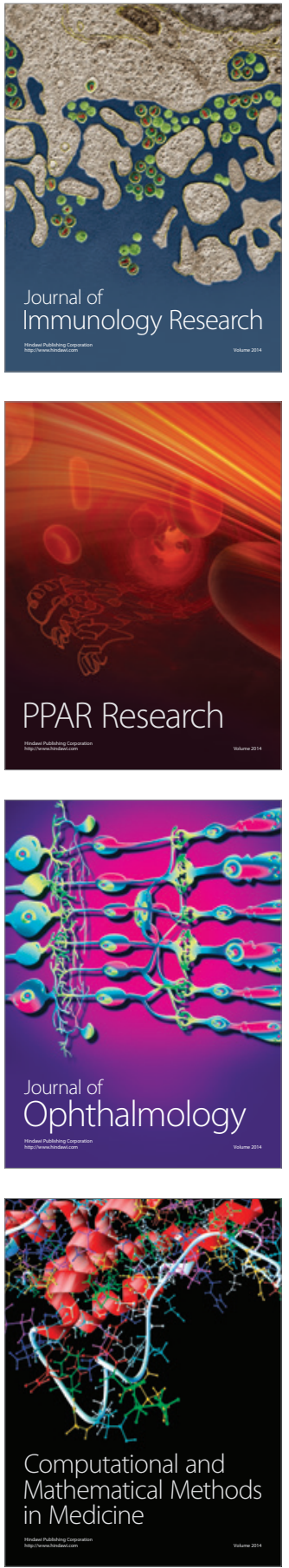

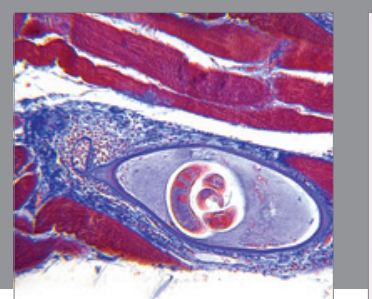

Gastroenterology Research and Practice

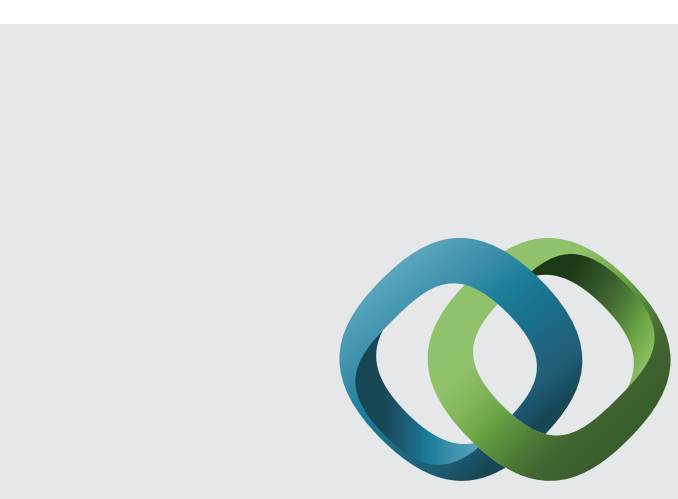

\section{Hindawi}

Submit your manuscripts at

http://www.hindawi.com
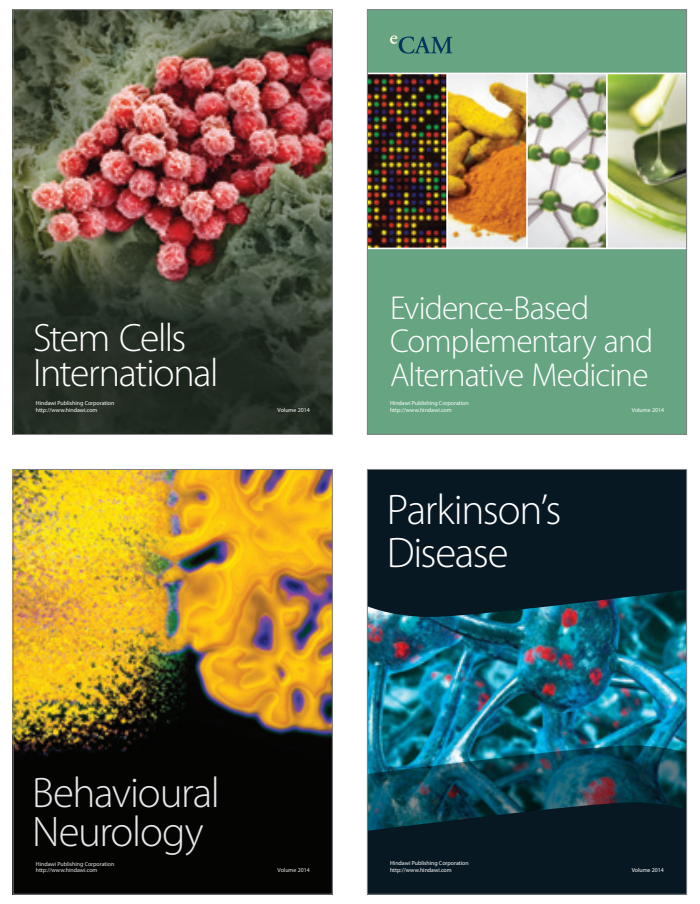
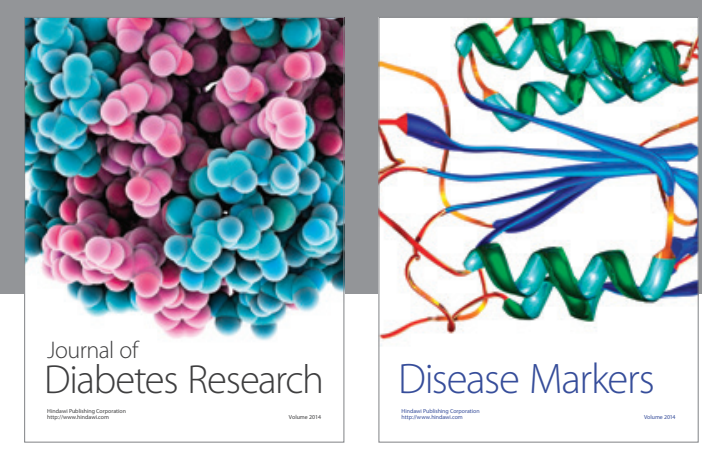

Disease Markers
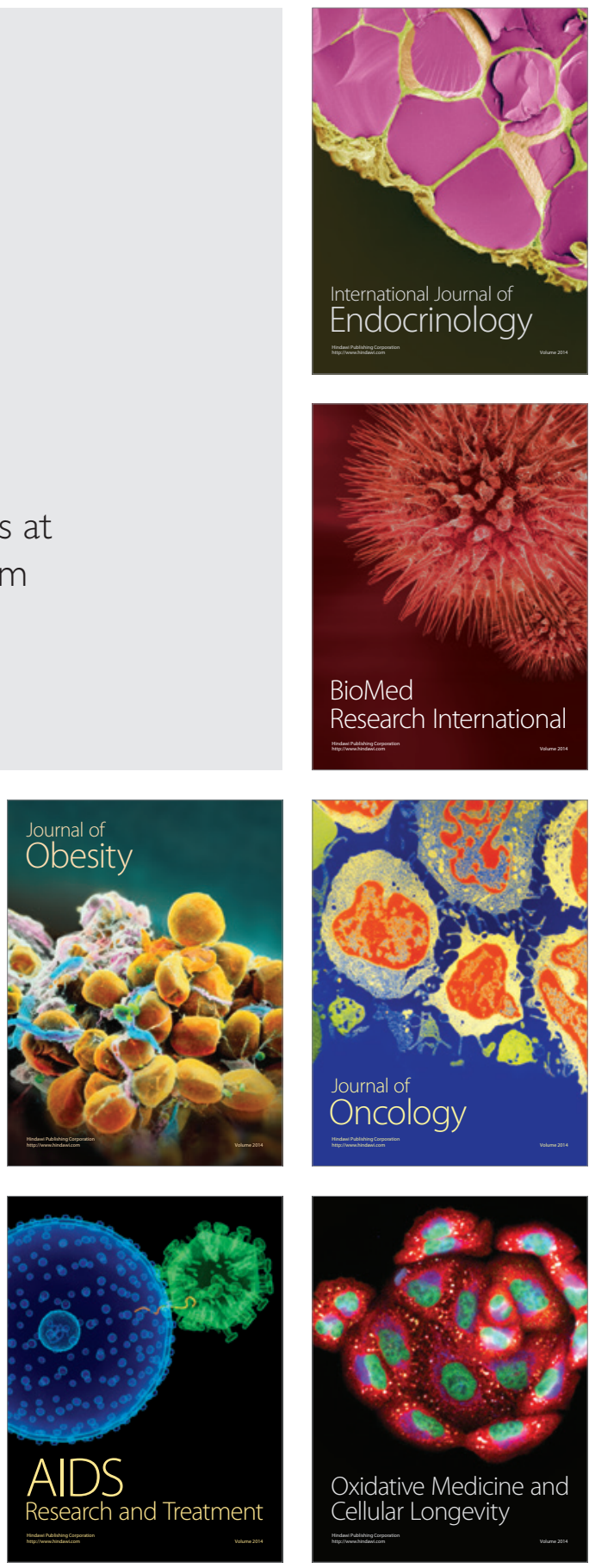